\title{
ANALISIS KANDUNGAN NUTRISI GRACILARIA EDULE (S.G. GMELIN) P.C. SILVA DAN GRACILARIA CORONOPIFOLIA J. AGARDH Untuk Pengembangan Perekonomian Masyarakat Pesisir
}

\author{
Nutrition Content Analysis To Gracilaria edule (S.G. Gmelin) P.C. Silva and Gracilaria \\ coronopifolia J. Agardh For Economic Development Of Coastal Communities
}

\author{
Jibrael Narto Bali Ate, Junet Franzisca da Costa, Theresia Pratiwi Elingsetyo S. \\ Program Studi Ilmu Gizi Fakultas Kedokteran dan Ilmu Kesehatan \\ Universitas Kristen Satya Wacana \\ 472013015@student.uksw.edu
}

\begin{abstract}
ABSTRAK
Pangan merupakan kebutuhan dasar manusia. Pengembangan bahan pangan bergizi dapat dilakukan dengan memanfaatkan sumber daya alam laut seperti rumput laut yang pemanfaatannya belum optimal. Penelitian ini bertujuan untuk mengetahui komposisi nutrisi total (kadar abu, kadar air, karbohidrat, lemak dan protein) dari rumput laut merah Gracilaria edule (S.G. Gmelin) P.C. Silva dan Gracilaria coronopifolia J. Agardh. Analisis proksimat menggunakan metode Apriyantono, et al, yang dimodifikasi. Penelitian menunjukkan bahwa Gracilaria edule (S.G. Gmelin) P.C. Silva mempunyai kadar lemak lebih tinggi dari Gracilaria coronopifolia J. Agardh yaitu 18,99\%; untuk kadar karbohidrat, Gracilaria coronopifolia J. Agardh mempunyai kadar karbohidrat yang lebih tinggi dari Gracilaria edule (S.G. Gmelin) P.C. Silva yaitu 1,38\%; sedangkan untuk kadar protein mempunyai kadar protein yang sama yaitu $0,01 \%$. Kadar air pada rumput laut Gracilaria edule (S.G. Gmelin) P.C. Silva lebih tinggi dari kadar air Gracilaria coronopifolia J. Agardh yaitu $72,95 \%$ \%; Untuk kadar abu, rumput laut Gracilaria coronopifolia J. Agardh mempunyai kadar abu lebih tinggi dari Gracilaria edule (S.G. Gmelin) P.C. Silva dan untuk serat kasar, rumput laut Gracilaria edule (S.G. Gmelin) P.C. Silva lebih tinggi yaitu 7,62\%. Rumput laut banyak mengandung zat-zat nutrisi penting yang diperlukan bagi tubuh manusia, seperti Protein, Karbohidrat dan Serat Kasar. Kandungan lemaknya yang rendah dan serat kasarnya yang cukup tinggi menyebabkan rumput laut baik untuk dikonsumsi. Dengan demikian, Gracilaria edule (S.G. Gmelin) P.C. Silva dan Gracilaria coronopifolia J. Agardh dapat dikembangkan menjadi makanan fungsional sehingga dapat meningkatkan permintaan pasar dan perekonomian masyarakat pesisir juga bisa meningkat.
\end{abstract}

Kata Kunci: Analisis proksimat, nutrisi, Gracilaria edule (S.G. Gmelin) P.C. Silva, Gracilaria coronopifolia J. Agardh.

\section{ABSTRACT}

Food is a basic human need. Development of nutritious food can be done by utilizing marine natural resources such as seaweed that utilization is not optimal. This study aims to determine the composition of total nutrients (ash content, water content, carbohydrates, fats and proteins) of red seaweed Gracilaria edule (S.G. Gmelin) P.C. Silva and Gracilaria coronopifolia J. Agardh. Proximate analysis using Apriyantono, et al, modified method. Research shows that Gracilaria edule (S.G. Gmelin) P.C. Silva has higher fat content than Gracilaria coronopifolia J. Agardh which is 18,99\%; for carbohydrate levels, Gracilaria coronopifolia J. Agardh has higher carbohydrate content than Gracilaria edule (S.G. Gmelin) P.C. Silva is 1.38\%; while for protein content has the same protein content that is 0,01\%. Water content in seaweed Gracilaria edule (S.G. Gmelin) P.C. Silva higher water content than Gracilaria coronopifolia J. Agardh that is 72,95\%\%; For ash content, seaweed Gracilaria coronopifolia J. Agardh has higher ash content than Gracilaria edule (S.G. Gmelin) P.C. Silva and for coarse fiber, seaweed Gracilaria edule (S.G. Gmelin) P.C. Silva is higher that is $7.62 \%$. Seaweed contains many essential nutrients necessary for the human body, such as Protein, Carbohydrates and Rough Fiber. Its low fat content and high coarse fiber make seaweed good for consumption. Thus, Gracilaria edule (S.G. Gmelin) P.C. Silva and Gracilaria 
coronopifolia J. Agardh can be developed into functional food so as to increase market demand and coastal economy can also increase.

Keywords: Proximate analysis, nutrition, Gracilaria edule (S.G. Gmelin) P.C. Silva, Gracilaria coronopifolia J. Agardh.

\section{PENDAHULUAN}

Pangan merupakan kebutuhan dasar manusia di samping sandang, perumahan, dan pendidikan. Pengembangan bahan pangan bergizi dapat dilakukan dengan memanfaatkan sumber daya alam laut seperti rumput laut yang pemanfaatannya belum optimal. Rumput laut merupakan salah satu komoditas yang memiliki nilai ekonomis cukup tinggi karena rumput laut banyak mengandung karaginan dan agar-agar yang sangat diperlukan dalam industri obat-obatan maupun industri kosmetik. Selain itu, sebagian rumput laut juga dimanfaatkan sebagai sayuran, obat tradisional dan bahan tambahan makanan sehingga rumput laut berpotensi untuk dikembangkan [1]. Potensi rumput laut di Indonesia memiliki peran dalam meningkatkan pendapatan masyarakat pesisir. Keberadaan rumput laut di seluruh perairan Indonesia sangat melimpah, terutama di pantai yang memiliki rataan terumbu karang.

Sumber daya alam laut merupakan sumber pangan yang sangat potensial. Pemanfaatan dan pengembangan sumber daya ini sangat didukung oleh kondisi perairan Indonesia. Luas wilayah Indonesia sebagian besar, yaitu dua per tiganya merupakan wilayah perairan. United Nation Convention on the Law of the Sea (UNCLOS) pada tahun 1982 melaporkan bahwa luas perairan Indonesia adalah 5,8 juta $\mathrm{km}^{2}$ dan didalamnya terdapat $27,2 \%$ dari seluruh spesies flora dan fauna di dunia. Rumput laut atau lebih dikenal dengan sebutan seaweed merupakan salah satu sumber daya hayati yang sangat melimpah di perairan Indonesia yaitu sekitar 8,6\% dari total biota di laut [2]. Luas wilayah yang menjadi habitat rumput laut di Indonesia mencapai 1,2 juta hektar atau terbesar di dunia [3]. Potensi rumput laut perlu terus digali, mengingat tingginya keanekaragaman rumput laut di perairan Indonesia.

Van Bosse melalui ekspedisi Laut Siboga pada tahun 1899-1900 melaporkan bahwa Indonesia memiliki kurang lebih 555 jenis dari 8.642 spesies rumput laut yang terdapat di dunia. Perairan Indonesia sebagai wilayah tropis memiliki sumber daya plasma nutfah rumput laut sebesar 6,42\% dari total biodiversitas rumput laut dunia [4,5]. Rumput laut dari kelas alga merah (Rhodophyceae) menempati urutan terbanyak dari jumlah jenis yang tumbuh di perairan laut Indonesia yaitu sekitar 452 jenis, setelah itu alga hijau (Chlorophyceae) sekitar 196 jenis dan alga coklat (Phaeophyceae) sekitar 134 [6]. Selain peran ekologis dan biologisnya dalam menjaga kestabilan ekosistem laut serta sebagai tempat hidup sekaligus perlindungan bagi biota lain, golongan makroalga ini memiliki potensi ekonomis yaitu sebagai bahan baku dalam industri dan kesehatan. Pada umumnya, konsumsi rumput laut oleh masyarakat pesisir didasarkan pada kebiasaan, tanpa pengetahuan mengenai kandungan nutrisi/potensi pemanfaatan rumput laut.

Pemanfaatan rumput laut sebagai bahan pangan sudah lama diketahui. Di Indonesia rumput laut sudah lama dimanfaatkan penduduk pantai untuk sayur, lalapan, acar, kue, puding, dan manisan. Pemanfaatan rumput laut secara ekonomis sudah dilakukan oleh beberapa negara. Cina dan Jepang sudah dimulai sejak tahun 1670 sebagai bahan obat-obatan, makanan tambahan, kosmetika, pakan ternak, dan pupuk organik. Pemanfaatan rumput laut di Indonesia sampai saat ini terbatas sebagai bahan makanan bagi penduduk yang tinggal di daerah pesisir dan belum banyak kalangan industri yang mau melirik potensi rumput laut ini. Rumput laut telah dimanfaatkan sebagai makanan seharihari bagi penduduk Jepang, Cina dan Korea, dan bahkan pada tahun 2005 nilai konsumsi rumput laut mencapai 2 milyar US\$. Ironisnya, di Indonesia, rumput laut hanya dibiarkan sebagai sampah lautan, mengapung, hanyut terbawa arus, ataupun terdampar di pinggir pantai [7]. Selain bahan pangan, manfaat rumput laut adalah sebagai sumber biopigmen. Eksplorasi sumber alternatif biopigmen selain dari tumbuhan dan makroorganisme lain perlu terus diupayakan, mengingat pigmen memiliki berbagai macam bioaktifitas yang menguntungkan bagi manusia. Potensi bioaktifitas pigmen klorofil di bidang kesehatan yaitu sebagai anti anemia, anti proteolitik, anti bakteri, antioksidan, 
meningkatkan immunitas, menstabilkan tekanan darah, pengganti sel-sel yang rusak, memperbaiki fungsi hati, menyembuhkan luka, dan lain-lain [8].

Hingga kini, masih sedikit rumput laut yang diketahui komposisi nutrisi dan potensi senyawa bioaktifnya. Terbatasnya informasi potensi dari rumput laut mendorong pelaksanaan penelitianpenelitian eksploratif seperti yang dilakukan dalam penelitian ini. Oleh sebab itu, tujuan penelitian ini adalah untuk mengetahui kadar nutrisi total (kadar abu total, kadar air, karbohidrat, lemak, protein) dan serat kasar pada Gracilaria coronopifolia J. Agardh dan Gracilaria edule (S.G. Gmelin) P.C. Silva yang melimpah di perairan Jepara, Jawa Tengah. Dengan diketahui nilai gizinya diharapkan hasil penelitian ini dapat memberikan informasi bagi industri pangan fungsional atau produk pangan lain guna meningkatkan permintaan pasar. Dengan demikian, masyarakat tidak hanya sebatas menjadikan rumput laut sebagai makanan tetapi juga dapat menjual rumput laut kepada investor, yang pada akhirnya akan meningkatkan pendapatan masyarakat di wilayah pesisir.

\section{METODE}

\section{Sampel}

Sampel yang digunakan pada penelitian ini adalah rumput laut yang biasa dikonsumsi oleh masyarakat sekitar pantai sepanjang daerah pesisir pantai, Jepara. Rumput Laut diperoleh dari tambak budidaya rumput laut di pesisir pantai Jepara. Sampel rumput laut tersebut diidentifikasi jenisnya dengan menggunakan jasa peneliti di Laboratorium Sistematika Tumbuhan Fakultas Biologi Universitas Gadjah Mada. Analisis komposisi nutrisi dilaksanakan di Laboratorium Biokimia Gizi Fakultas Kedokteran Dan Ilmu Kesehatan dan Laboratorium Fakultas Sains dan Matematika, Universitas Kristen Satya Wacana.

Sampel yang diperoleh dari Tambak budidaya rumput laut di pesisir pantai Jepara dikeringkan selama $2 \frac{1}{2}$ hari dengan cara dijemur. Setelah sampel rumput lautnya kering, kemudian sampel dihaluskan dengan menggunakan alat penepung hingga sampelnya halus. Selanjutnya, sampel yang sudah dihaluskan, diambil sesuai kebutuhan untuk dilakukan analisis proksimat (kadar air, kadar abu, protein, lemak, serat kasar dan karbohidrat). Sampel rumput laut yang digunakan ada dua jenis yaitu Gracilaria edule (S.G. Gmelin) P.C. Silva dan Gracilaria coronopifolia J. Agardh.

\section{Metode Analisis}

Seluruh analisis proksimat (kadar abu total, kadar air, kadar lemak total, kadar protein total, serat kasar dan kadar karbohidrat) dilakukan berdasarkan metode analisis proksimat menurut Apriyantono, et al, (1989) yang dimodifikasi.

\section{Analisis Kadar Air}

Sebanyak 1-2 g contoh ditimbang dalam sebuah wadah yang sudah diketahui bobotnya. Kadar air diukur dengan menggunakan oven bersuhu $105^{\circ} \mathrm{C}$ selama 3 jam. Setelah itu didinginkan dalam desikator dan ditimbang. Pekerjaan tersebut diulang sehingga mendapat bobot yang konstan.

Kadar Air dihitung dengan rumus

$$
\begin{aligned}
& \text { Kadar Air }(\%)=\frac{A-B}{C} \times 100 \% \\
& \text { Keterangan : } \\
& \text { A = cawan + contoh kering }(\mathrm{g}) \\
& \mathrm{B}=\text { cawan kosong }(\mathrm{g}) \\
& \mathrm{C}=\text { bobot contoh }(\mathrm{g})
\end{aligned}
$$

\section{Analisis Kadar Abu}

Sebanyak $2 \mathrm{~g}$ contoh ditimbang dalam sebuah cawan porselin yang telah dikeringkan dan diketahui bobotnya. Kemudian diarangkan dengan pemanas bunsen hingga tidak mengeluarkan asap lagi. Cawan porselin berisi contoh yang sudah diarangkan kemudian dimasukkan ke dalam tanur bersuhu $600^{\circ} \mathrm{C}$ hingga proses pengabuan sempurna. Cawan porselin berisi abu didinginkan dalam desikator dan ditimbang hingga mencapai bobot tetap. 
Kadar Abu dihitung dengan rumus

$$
\begin{aligned}
& \text { Kadar Abu }(\%)=\frac{A-B}{C} \times 100 \% \\
& \text { Keterangan : } \\
& \text { A = cawan + contoh kering }(\mathrm{g}) \\
& \mathrm{B}=\text { cawan kosong }(\mathrm{g}) \\
& \mathrm{C}=\text { bobot contoh }(\mathrm{g})
\end{aligned}
$$

\section{Analisis Kadar Lemak (Woodman, 1941)}

Timbang dengan teliti $2 \mathrm{~g}$ bahan yang telah dihaluskan (sebaiknya yang kering dan lewat 40 mesh). Campur dengan pasir yang telah dipijarkan sebanyak $8 \mathrm{~g}$ dan masukkan ke dalam tabung ekstraksi Soxhlet dalam Thimble. Alirkan air pendingin melalui kondensor. Pasang tabung ekstraksi pada alat distilasi Soxhlet dengan pelarut petroleum ether secukupnya selama 4 jam. Setelah residu dalam tabung ekstraksi diaduk, ekstraksi dilanjutkan lagi selama 2 jam dengan pelarut yang sama. Petrolium ether yang telah mengandung ekstrak lemak dan minyak dipindahkan ke dalam botol timbang yang bersih dan diketahui beratnya kemudian uapkan dengan penangas air sampai agak pekat. Teruskan pengeringan dalam oven $100^{\circ} \mathrm{C}$ sampai berat konstan.

Kadar Lemak dihitung dengan rumus:

$$
\begin{aligned}
& \text { Kadar Lemak }(\%)=\frac{A-B}{C} \times 100 \% \\
& \text { Keterangan : } \\
& \text { A = cawan }+ \text { contoh kering }(\mathrm{g}) \\
& \mathrm{B}=\text { cawan kosong }(\mathrm{g}) \\
& \mathrm{C}=\text { bobot contoh }(\mathrm{g})
\end{aligned}
$$

\section{Analisis Kadar Protein (Penentuan N-Total. Cara Semi-Mikro- Kjeldahl)}

Ambil $10 \mathrm{ml}$ susu atau larutan protein dan masukkan ke dalam labu takar $100 \mathrm{ml}$ dan encerkan dengan aquades sampai tanda. Ambil $10 \mathrm{ml}$ dari larutan ini dan masukkan ke dalam labu kjeldahl $500 \mathrm{ml}$ dan tambahkan $10 \mathrm{ml} \mathrm{H}_{2} \mathrm{SO}_{4}(93-98 \%$ bebas $\mathrm{N})$. Tambahkan 5 g campuran $\mathrm{Na}_{2} \mathrm{SO}_{4}-$ $\mathrm{HgO}(20: 1)$ untuk katalisator. Didihkan sampai jernih dan lanjutkan pendidihan 30 menit lagi. Setelah dingin, cucilah dinding dalam labu kjeldahl dengan aquades dan didihkan lagi selama 30 menit. Setelah dingin, tambahkan $140 \mathrm{ml}$ aquades dan tambahkan $35 \mathrm{ml}$ larutan $\mathrm{NaOH} . \mathrm{Na}_{2} \mathrm{SO}_{3}$ dan beberapa butiran zink. Kemudian lakukan distilasi ; distilat ditampung sebanyak $100 \mathrm{ml}$ dalam Erlenmeyer yang berisi $25 \mathrm{ml}$ larutan jenuh asam borat dan beberapa tetes indikator metil merah/metilen biru. Titrasilah larutan yang diperoleh dengan $0,02 \mathrm{~N} \mathrm{HCl}$. Hitunglah total $\mathrm{N}$ atau \% protein dalam contoh.

Perhitungan jumlah total $\mathrm{N}$ :

$$
\begin{aligned}
& \text { Jumlah N Total }(\%)=\frac{m l \mathrm{HCl} \times \mathrm{N} \mathrm{HCl} \times 14,008 \times f \frac{m g}{m l} \times 100 \%}{m l \text { larutan } / \text { bobot contoh }} \\
& \text { Keterangan } \quad: \\
& \mathrm{f}=\text { faktor pengenceran, dalam contoh petunjuk ini } \\
& \text { besarnya } \mathrm{f}=6,25 \mathrm{mg} / \mathrm{ml} \\
& \mathrm{N} \mathrm{HCl}=\text { normalitas } \mathrm{HCl} \mathrm{ml} \mathrm{larutan/bobot} \mathrm{contoh}(\mathrm{g})
\end{aligned}
$$




\section{Analisis Kadar Serat Kasar (Metode Refluk)}

Serat kasar merupakan residu dari bahan makanan atau pertanian setelah diperlakukan dengan asam atau alkali mendidih, dan terdiri dari selulosa, dengan sedikit lignin dan pentosan. Haluskan bahan sehingga dapat melalui ayakan diameter $1 \mathrm{~mm}$ dan campurlah baik-baik. Kalau bahan tak dapat dihaluskan, hancurkan sebaik mungkin. Timbang $2 \mathrm{~g}$ bahan kering dan ekstraksi lemaknya dengan Soxhlet. Kalau bahan sedikit mengandung lemak, misalnya sayur-sayuran, gunakan $10 \mathrm{~g}$ bahan ; tidak perlu dikeringkan dan diekstraksi lemaknya. Pindahkan bahan ke dalam Erlenmeyer $600 \mathrm{ml}$. Tambahkan $200 \mathrm{ml}$ larutan $\mathrm{H}_{2} \mathrm{SO}_{4}$ mendidih $\left(1,25 \mathrm{~g} \mathrm{H}_{2} \mathrm{SO}_{4}\right.$ pekat/ $\left.100 \mathrm{ml}=0,255 \mathrm{~N} \mathrm{H}_{2} \mathrm{SO}_{4}\right)$ dan tutuplah dengan pendingin balik, didihkan selama 30 menit dengan kadang kala digoyanggoyangkan. Saring suspensi melalui kertas saring dan residu yang tertinggal dalam erlenmeyer dicuci dengan aquades mendidih. Cucilah residu dalam kertas saring sampai air cucian tidak bersifat asam lagi (uji dengan kertas lakmus). Pindahkan secara kuantitatif residu dari kertas saring ke dalam erlenmeyer kembali dengan spatula, dan sisanya dicuci dengan larutan $\mathrm{NaOH}$ mendidih ( 1,25 g NaOH/100ml $=0,313 \mathrm{~N} \mathrm{NaOH}$ ) sebanyak $200 \mathrm{ml}$ sampai semua residu masuk ke dalam erlenmeyer. Didihkan dengan pendingin balik sambil kadang kala digoyang - goyangkan selama 30 menit. Saringlah melalui kertas saring kering yang diketahui beratnya atau krus Gooch yang telah dipijarkan dan diketahui beratnya, sambil dicuci dengan larutan K2SO4 $10 \%$. Cuci lagi residu dengan aquades mendidih dan kemudian dengan lebih kurang $15 \mathrm{ml}$ alkohol $95 \%$. Keringkan kertas saring atau krus dengan isinya pada $110^{\circ} \mathrm{C}$ sampai berat konstan (1-2 jam), dinginkan dalam desikator dan timbang.

Kadar Serat Kasar dihitung dengan rumus :

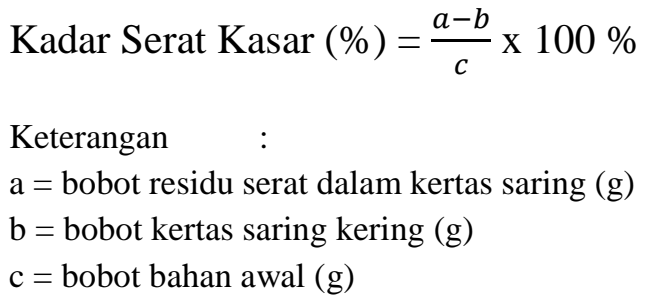

Analisis Kadar Karbohidrat by difference

Kadar Karbohidrat dihitung dengan rumus

$$
\begin{aligned}
& \text { Kadar Karbohidrat } \\
& (\% \mathrm{KH})=100 \%-(\mathrm{A}+\mathrm{B}+\mathrm{C}+\mathrm{D}+\mathrm{E}) \\
& \text { Keterangan }: \\
& \mathrm{A}=\text { Kadar air } \\
& \mathrm{B}=\text { Kadar abu } \\
& \mathrm{C}=\text { Kadar lemak } \\
& \mathrm{D}=\text { Kadar protein } \\
& \mathrm{E}=\text { Kadar serat kasar }
\end{aligned}
$$

\section{Analisis Data}

Analisis data dilakukan secara deskriptif kuantitatif. Pengolahan data pada penelitian ini menggunakan Microsoft Excel 2010.

\section{HASIL}

Sampel penelitian yang digunakan dalam penelitian ditunjukkan pada Gambar $\mathbf{1}$ dan hasil analisis proksimat (kadar air, abu, lemak, protein, serat kasar, dan karbohidrat) dari kedua sampel diperlihatkan pada Tabel 1. Rumput laut Gracilaria edule (S.G. Gmelin) P.C. Silva mempunyai kadar air sebanyak 72,95\% ; kadar abu 3,19\%; kadar lemak 1,38 \% ; kadar protein 0,01\% ; serat kasar 7,62 \% ; dan kadar karbohidrat total sebesar 14,84 \%, sedangkan Gracilaria coronopifolia J. Agardh mempunyai kadar air, abu, lemak, protein, serat kasar, dan karbohidrat 
berturut-turut adalah $50,92 \%, 27,12 \%, 0,09 \%, 0,01 \%, 2,87 \%$ dan $18,99 \%$.

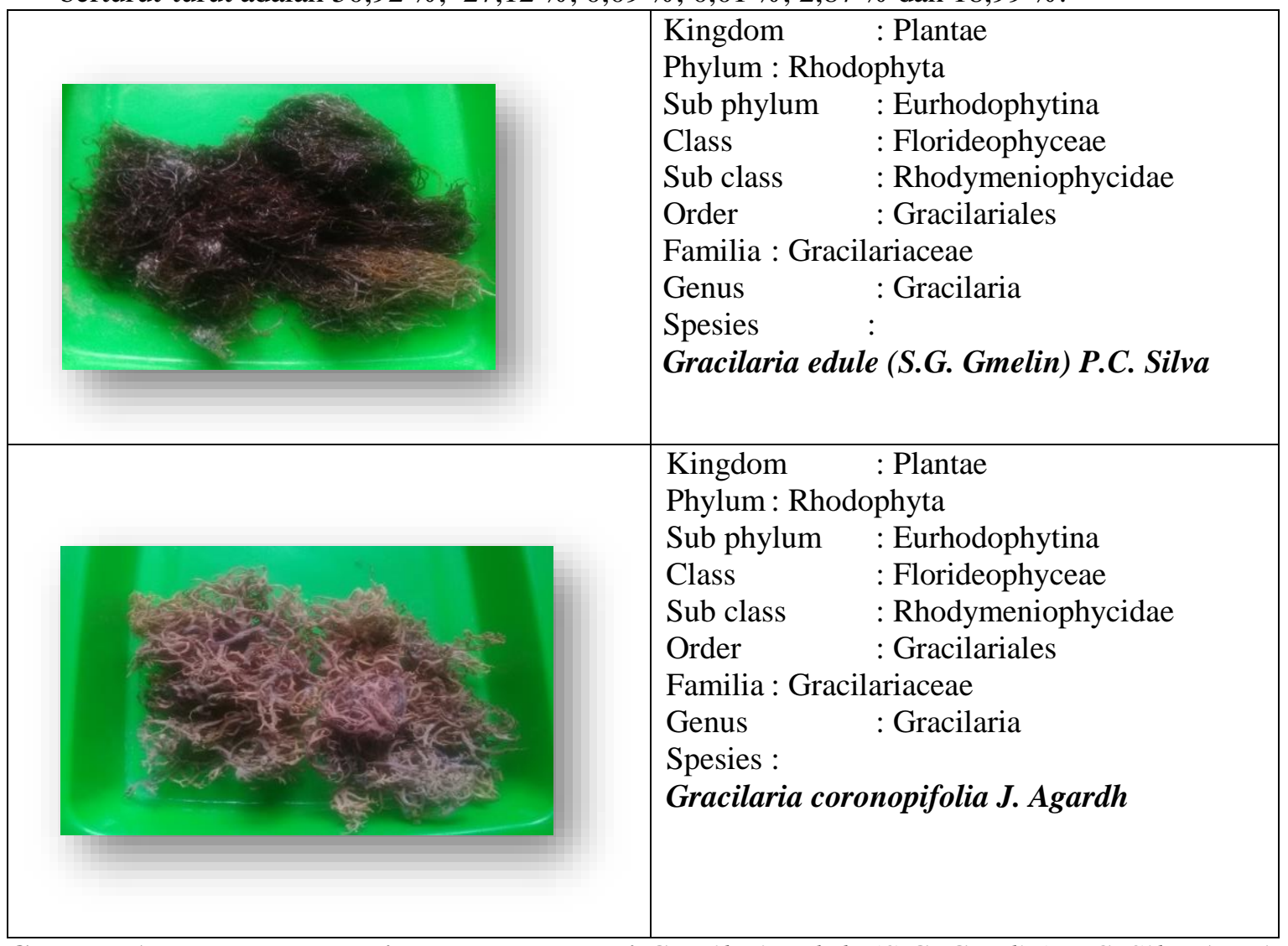

Gambar 1. Foto sampel kering dan taksonomi Gracilaria edule (S.G. Gmelin) P.C. Silva (atas) dan Gracilaria coronopifolia J. Agardh (bawah).

Tabel 1. Hasil kadar air, abu, lemak, protein, serat kasar dan karbohidrat

\begin{tabular}{lllllll}
\hline \multicolumn{1}{c}{ Sampel } & $\begin{array}{c}\text { Kada } \\
\text { r Air }\end{array}$ & $\begin{array}{c}\text { Kadar } \\
\text { Abu }\end{array}$ & $\begin{array}{c}\text { Kadar } \\
\text { Lemak }\end{array}$ & $\begin{array}{c}\text { Kadar } \\
\text { Protei } \\
\mathbf{n}\end{array}$ & $\begin{array}{c}\text { Serat } \\
\text { Kasar }\end{array}$ & $\begin{array}{c}\text { Kadar } \\
\text { Karbohidrat }\end{array}$ \\
\hline $\begin{array}{l}\text { Gracilaria edule (S.G. } \\
\text { Gmelin) P.C. Silva (\%) }\end{array}$ & 72.95 & 3.19 & 1.38 & 0.01 & 7.62 & 14.84 \\
$\begin{array}{l}\text { Gracilaria } \\
\text { coronopifolia } \\
\text { J. Agardh (\%) }\end{array}$ & 50.92 & 27.12 & 0.09 & 0.01 & 2.87 & 18.99 \\
\hline
\end{tabular}

\section{KADAR NUTRISI TOTAL}

- Gracilaria edule (S.G. Gmelin) P.C. Silva (\%) पGracilaria coronopifolia J. Agardh (\%)

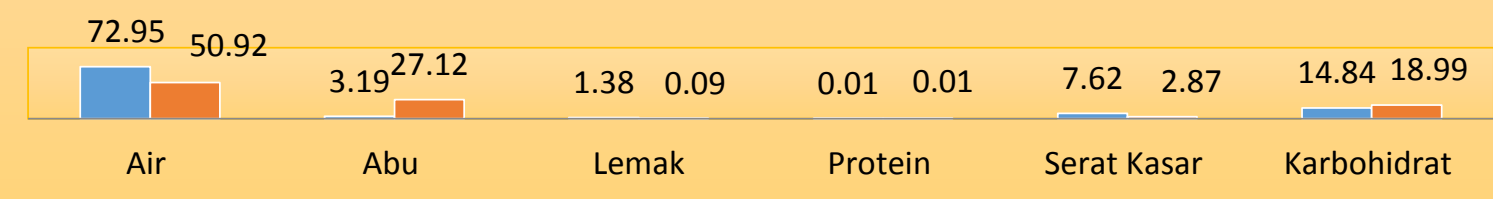

Gambar 2. Profil Komposisi Nutrisi Gracilaria Edule (S.G. Gmelin) P.C. Silva dan Gracilaria Coronopifolia J. Agardh. 
Berdasarkan data pada Gambar 1., terlihat bahwa kadar air Gracilaria Edule (S.G. Gmelin) P.C. Silva $(72,95 \%)$ dan kadar lemak (1,38 \%) lebih tinggi dari Gracilaria Coronopifolia J. Agardh, sedangkan Gracilaria Coronopifolia J. Agardh mempunyai kadar abu lebih tinggi (27,12 \%) dari pada Gracilaria Edule (S.G. Gmelin) P.C. Silva. Kadar protein pada rumput laut Gracilaria Edule (S.G. Gmelin) P.C. Silva dan Gracilaria Coronopifolia J. Agardh yang dianalisis menggunakan metode kjehdal mempunyai kadar protein yang sama yaitu $0,01 \%$. Kadar serat kasar yang dianalisis menggunakan metode refluk diperoleh rumput laut jenis Gracilaria Edule (S.G. Gmelin) P.C. Silva mempunyai kadar serat kasar lebih tinggi dari pada rumput laut jenis Gracilaria Coronopifolia J. Agardh yaitu 7,62 \%. Sedangkan kadar karbohidrat (by difference) pada Gracilaria Coronopifolia J. Agardh ditemukan lebih tinggi dari pada Gracilaria Edule (S.G. Gmelin) P.C. Silva yaitu 18,99 \%. Jenis Gracilaria Edule (S.G. Gmelin) P.C. Silva yaitu 18,99\%.

\section{PEMBAHASAN}

Hasil analisis komposisi kimia Gracilaria Edule (S.G. Gmelin) P.C. Silva dan Gracilaria Coronopifolia J. Agardh menunjukkan perbedaan, kecuali kadar protein. Salamah dkk. (2006) juga menemukan bahwa komposisi kimia dari rumput laut bervariasi dari setiap spesies. Kualitas rumput laut dapat dipengaruhi oleh faktor internal (keragaman individu) dan faktor eksternal (lingkungan). Faktor lingkungan seperti umur, suhu, cahaya, kadar garam, musim, panen, gerakan airdan zat hara habitat rumput laut dapat memengaruhi proses fotosintesis yang secara tidak langsung akan memengaruhi kandungan protein, lemak, serat kasar, dan karbohidrat rumput laut [12].

\section{Kadar air}

Komponen utama Gracilaria Edule (S.G. Gmelin) P.C. Silva dan Gracilaria Coronopifolia J. Agardh adalah air karena tercatat lebih dari 50\%. Kadar air dalam bahan pangan akan mempengaruhi daya simpan bahan pangan tersebut. Kadar air dapat dipengaruhi oleh proses penyimpanan bahan mulai dari waktu pemanenan sampai bahan diolah menjadi produk. Semakin tinggi kadar air suatu bahan pangan maka semakin tinggi kemungkinan bahan tersebut untuk mengalami kerusakan. Hal ini disebabkan karena adanya mikroorganisme seperti kapang dan berbagai jenis kutu yang dapat merusak produk [13].

\section{Kadar abu}

Kadar abu dalam bahan pangan menunjukkan kandungan total mineralnya. Berdasarkan hasil analisis, kadar abu Gracilaria Coronopifolia J. Agardh (27,12\%) lebih tinggi dari Gracilaria Edule (S.G. Gmelin) P.C. Silva (3,19\%). Kandungan mineral rumput laut tidak tertandingi oleh sayuran yang berasal dari darat. Fraksi mineral dari beberapa rumput laut mencapai lebih dari $36 \%$ berat kering. Dua mineral utama yang terkandung pada sebagian besar rumput laut adalah iodin dan kalsium [14]. Rumput laut juga merupakan sumber kalsium yang sangat penting. Kandungan kalsium dalam rumput laut dapat mencapai $7 \%$ dari berat kering dan 25-34\% dari rumput laut yang mengandung kapur [15]. Kandungan mineral seperti yang telah disebutkan di atas memberikan efek yang sangat baik bagi kesehatan. Iodin misalnya, secara tradisional telah digunakan untuk mengobati penyakit gondok. Iodin mampu mengendalikan hormon tiroid, yaitu hormon yang berperan dalam pembentukan gondok. Mereka yang telah membiasakan diri mengkonsumsi rumput laut terbukti terhindar dari penyakit gondok karena kandungan iodin yang tinggi di dalam rumput laut. Kandungan mineral lain yang juga tak kalah penting adalah kalsium. Konsumsi rumput laut sangat berguna bagi ibu yang sedang hamil, para remaja, dan orang lanjut usia yang kemungkinan dapat terkena resiko kekurangan (defisiensi) kalsium [14].

Sekalipun kadar total mineral Gracilaria Edule (S.G. Gmelin) P.C. Silva $(3,19 \%)$ lebih rendah dari Gracilaria Coronopifolia J. Agardh (27,12\%), namun kedua rumput laut ini dapat menjadi sumber mineral penting bagi tubuh. Bahkan jika dimakan dalam jumlah sedikit saja sudah memenuhi kebutuhan mineral tubuh [16].

\section{Kadar lemak}

Berdasarkan analisis kadar lemak rumput laut Gracilaria Edule (S.G. Gmelin) P.C. Silva dan Gracilaria Coronopifolia J. Agardh yaitu 1,38\% dan 0,09\%. Khairy and El-Shafay (2013) dan Fleurence (2016) mengemukakan bahwa kadar lemak semua jenis rumput laut sangat rendah yakni berkisar antara 0,9-4,0\% berat kering. Dengan demikian, kadar lemak Gracilaria Edule (S.G. 
Gmelin) P.C. Silva dan Gracilaria Coronopifolia J. Agardh yang ditemukan masih dalam selang kadar lemak yang ditemukan dari berbagai jenis rumput laut.

Menurut de Almeida dkk. (2011), lipid yang banyak terdapat pada genus Gracilaria adalah prostaglandin dan kelompok steroid seperti kolesterol dan clinoasterol. Rumput laut merah dan coklat dilaporkan banyak mengandung asam lemak dengan 20 atom karbon seperti asam eikosapentanoat dan asam arakidonat [19]. Kedua asam lemak tersebut berperan dalam mencegah inflamatori (peradangan) dan penyempitan pembuluh darah. Hasil penelitian membuktikan bahwa ekstrak lipid beberapa rumput laut memiliki aktivitas antioksidan dan efek sinergisme terhadap tokoferol (senyawa antioksidan yang sudah banyak digunakan) [20,21].

\section{Kadar protein}

Kandungan protein pada rumput laut dipengaruhi oleh jenis dan daerah tumbuhnya. Bahkan pada jenis rumput laut yang sama dapat ditemukan kandungan protein yang berbeda. Hal ini dikarenakan kondisi perairan tempat tumbuhnya bibit rumput laut yang ditanam. Kadar protein pada rumput laut Gracilaria Edule (S.G. Gmelin) P.C. Silva dan Gracilaria Coronopifolia J. Agardh dalam penelitian ini adalah sama $(0,01 \%)$. Hasil kadar protein kedua jenis rumput laut merah ini sangat rendah jika dibandingkan dengan temuan-temuan pada jenis rumput laut merah lainnya, karena kadar protein pada beberapa jenis rumput laut merah lain bisa mencapai $47 \%$ berat kering [16,22]. Kadar ini lebih besar bila dibandingkan dengan kandungan protein yang ada di sayuran yang kaya protein seperti kacang kedelai yang mempunyai kandungan protein sekitar $35 \%$ berat kering [23]. Rendahnya kadar protein kedua jenis rumput laut ini diperkirakan karena kedua rumput laut ini merupakan hasil budidaya yang lingkungannya tidak begitu bervariasi.

\section{Kadar karbohidrat}

Hasil analisis kadar karbohidrat pada rumput laut Gracilaria Edule (S.G. Gmelin) P.C. Silva dan Gracilaria Coronopifolia J. Agardh yaitu $14,84 \%$ dan 18,99\%. Hasil analisis kandungan kadar karbohidrat lebih kecil disebabkan karena rumput laut yang dianalisis diambil dari hasil budidaya, bukan dari laut secara langsung.

Kandungan polisakarida yang terdapat di dalam rumput laut berperan dalam menurunkan kadar lipid di dalam darah dan tingkat kolesterol serta memperlancar sistem pencernaan makanan. Komponen polisakarida dan serat juga mengatur asupan gula di dalam tubuh, sehingga mampu mengendalikan tubuh dari penyakit diabetes. Beberapa polisakarida rumput laut seperti fukoidan (dari alga coklat) juga menunjukkan beberapa aktivitas biologis lain yang sangat penting bagi dunia kesehatan. Aktivitas tersebut seperti antitrombotik, antikoagulan, antikanker, antiproliferatif (antipembelahan sel secara tak terkendali), antivirus, dan antiinflamatori (antiperadangan) [19,24].

\section{Kadar serat kasar}

Serat pangan merupakan senyawa yang tidak dapat diserap tubuh tetapi memiliki manfaat dalam membantu proses perncernaan makanan. Serat pangan merupakan salah satu komponen penyusun karbohidrat dimana pada rumput laut komponen terbesarnya adalah senyawa gumi [6]. Hasil analisis kadar serat pangan pada rumput laut Gracilaria Edule (S.G. Gmelin) P.C. Silva dan Gracilaria Coronopifolia J. Agardh yaitu $7,62 \%$ dan $2,87 \%$. Nilai ini masih rendah dibandingkan dengan kandungan serat rumput laut pada umumnya yang dapat mencapai $30-40 \%$ berat kering dengan persentase lebih besar pada serat larut air. Kandungan serat larut air rumput laut jauh lebih tinggi dibandingkan dengan tumbuhan daratan yang hanya mencapai sekitar 15\% berat kering [19]. Kadar serat pangan pada rumput laut bergantung pada spesies dan tempat hidup dari rumput laut tersebut.

Rumput laut Gracilaria Edule (S.G. Gmelin) P.C. Silva dan Gracilaria Coronopifolia J. Agardh mempunyai kandungan lemak sangat rendah dan kaya akan serat. Oleh sebab itu, kedua rumput laut ini aman dikonsumsi dalam jumlah banyak. Kandungan lemaknya yang rendah menyebabkan rumput laut digunakan sebagai salah satu bahan penyusun utama pada makanan diet rendah lemak.

Gracilaria Edule (S.G. Gmelin) P.C. Silva dan Gracilaria Coronopifolia J. Agardh merupakan sumber daya alam laut yang berpotensi untuk dimanfaatkan dalam industri pangan fungsional. Tentunya setelah mengetahui kadar nutrisi dan manfaat rumput laut dalam aspek kesehatan, masyarakat akan semakin terbuka pikirannya untuk mengembangkan potensi kedua jenis rumput laut ini. 


\section{KESIMPULAN DAN SARAN}

Gracilaria Edule (S.G. Gmelin) P.C. Silva dan Gracilaria Coronopifolia J. Agardh mengandung zat-zat nutrisi penting yang diperlukan bagi tubuh manusia, seperti protein, karbohidrat, lemak, dan serat kasar. Kandungan lemaknya yang rendah dan serat kasarnya yang cukup tinggi menyebabkan rumput laut baik untuk dikonsumsi sehari-hari. Diharapkan hasil penelitian ini dapat diketahui oleh masyarakat pesisir perairan Jepara dan tempat lain yang belum membudidayakan kedua jenis rumput laut ini sehingga dapat meningkatkan pemanfaatan rumput laut ini ke industri yang lebih luas guna peningkatan perekonomian masyarakat pesisir tetapi juga secara tidak langsung memberikan kontribusi positif pemerintah dan perusahaan yang bergerak di bidang terkait.

\section{KEPUSTAKAAN}

Kadi, A. 2004. Potensi Rumput Laut dibeberapa Perairan Pantai Indonesia. Jurnal Oseana. XXIX: 25-36

Dahuri, Rokhmin. 1998. Coastal Zone Management in Indonesia: Issues and Approaches.Journal of Coastal Development 1, No. 2. 97-112.

Wawa, J. E. 2005. Pemerintah Provinsi Harus Segera Menyiapkan Lahan Pembibitan. Kompas, 27 Juli 2005. www.kompas.com. (10 Januari 2009)

Santosa, G.W. 2003. Budidaya Rumput Laut. Program Community College Industri Kelautan dan Perikanan. Universitas Diponegoro. Semarang.

Surono, A. 2004. Profil Rumput Laut Indonesia. Direktorat Jenderal Perikanan Budidaya. Departemen Kelautan dan Perikanan. Jakarta.

Winarno, F, G. 1996. Teknologi Pengolahan Rumput Laut. Pustaka Sinar Harapan. Jakarta.107 Hlm.

Yunizal, 1999. Teknologi Ekstraksi Alginat dari Rumput Laut Coklat (Phaeophyceae). Instalasi Penelitian Perikanan Laut Slipi, Balai Penelitian Perikanan Laut, Pusat Penelitian dan Pengembangan Perikanan. Jakarta.

Suparmi, O.K. Radjasa, and L. Limantara. 2007. Mikroorganisme yang Berasosiasi Dengan Sponge: Potensinya Sebagai Sumber Biopigmen dan Upaya Budidayanya. Jurnal Masyarakat Aquakultura Indonesiana, 8 (2):121-133, Agustus 2007.

Apriyantono A, Fardiaz D, Puspitasari NL., Sedarnawati, Budiyanto S. 1989. Analisis Pangan. Bogor : Pusat Antar Universitas, Institut Pertanian Bogor.

Woodman, A.G., 1941. Food Analysis 4th Edition, Mc. Graw Hill Book Company, Inc. New York. Salamah E, Anna CE, Yuni R. 2006. Pemanfaatan Gracilaria sp. dalam pembuatan permen jelly. Buletin Teknologi Hasil Perikanan 9(1): 38-46.

Salamah E, Anna CE, Yuni R. 2006. Pemanfaatan Gracilaria sp. dalam pembuatan permen jelly. Buletim Teknologi Hasil Perikanan 9(1): 38-46.

Ito K, Hori K. 1989. Seaweed: chemical composition and Potentional Uses. Food Reviews International 5(1):101-144.

Syarief R dan Halid D. 1993. Teknologi Penyimpanan Pangan. Argan: Jakarta

Fitton, Helen. 2005. Marine Algae and Health: A Review of The Scientific and Historical Literature.

Ramazanov, Z., 2006. New wave of health from the sea. Nutraceuticals World 2(6):38-39.

Fleurence, J. Seaweed as Food, In : Seaweed in Health and Disease Prevention (ed) Fleurence, J. and Levine, I., Elsevier Inc. Oxfrod, UK. p.156

Khairy, H.M., and S.M. El-Shafay. 2013. Seasonal variations in the biochemical composition of some common seaweed species from the coast of Abu Qir Bay, Alexandria, Egypt. Oceanologia, 55(2):435-452. doi:10.5697/oc.552.435

de Almeida, CLF., de S. Falcão, H., de M. Lima, GR., de A. Montenegro, C., Lira, NS., de AthaydeFilho, PF., et al., 2011. Bioactive from marine Alga of the Genus Garcilaria. Int.J.Mol.Sci. 2011.12:4550-4573.doi:10.3390/ijms12074550

Burtin, Patricia. 2003. Nutritional Value of Seaweeds. Electron. J. Environ. Agric. Food Chem. 2(4): 498-503.

Anggadiredja, J. T., A. Zatnika, H. Purwoto dan S. Istini. 2006. Rumput Laut. Cetakan I. Jakarta : Penerbit Swadaya 
Shanab, S., M., M., 2007. Antioxidant and antibiotic activities of some seaweeds (Egyptian Isolates). International Journal of Agriculture and Biology 9(2):220-225.

Mohd Hani Norziah, Chio Yen Ching. 2000. Nutritional composition of edible seaweed Gracilaria changgi. Food Chemistry 68: 69-76.

Almatsier, Sunita. 2005. Prinsip Dasar Ilmu Gizi. PT. Gramedia Pustaka Utama, Jakarta.

Shiratori, K., K. Ohgami, I. Ilieva, X.-H. Jin, Y. Koyama, K. Miyashita, K. Yoshida, S. Kase,dan S. Ohno. 2005. Effect of fucoxanthin on lipopolysaccharide induced inflammation in vitro and sin vivo. Exp. Eye Res. 81: 442-428. 